\title{
THE INTERNATIONAL BUSINESS MANAGEMENT ENVIRONMENT IN THE BRIC(S) BLOC
}

\author{
R. F. LITTRELL* \\ National Research University Higher School of Economics at St.Petersburg, \\ Russia ${ }^{\mathrm{a}}$ \\ P. RAMBURUTH \\ UNSW Business School, University of New South Wales, Australia ${ }^{b}$
}

\begin{abstract}
The BRIC countries (Brazil, Russia, India and China) were identified as the fastest growing emerging economies by the economist Jim O'Neill in 2001. He created the acronym BRIC (which became BRICS in 2010 to include South Africa) and raised their profiles. Some researchers viewed the rise of BRIC(S) as phenomenal, others were more cautious. Scholars such as [Sinha, Dorschner, 2010] noted the disparate nature of the BRIC countries, being separated geographically, culturally and politically. Others (e.g. [Armijo, Burges, 2007; Tudoroiu, 2012]) noted a lack of conceptualization of BRIC(S) as a group, that is having an array of similar characteristics. This article reviews the international business management environment in the BRIC(S) bloc, finding uncertainties about the sustainability of their upward trajectories. Historically and statistically, emerging economies that secure rapid economic growth seem unable to sustain it after a decade, evident in the decline of the economic fortunes of BRIC(S). This paper provides statistical insights into BRIC(S) individual and bloc performance and discusses alternate clusters of emerging economies and predictions (e.g. FIG, MINT, MIST, etc.). The discussion briefly considers the role of the New Development Bank (2015), provision of development finance to BRIC(S) and other emerging economies, and positioning in relation to existing financial institutions. The paper concludes with suggestions for a more considered assessment of emerging economies and their role in the global economy.
\end{abstract}

Keywords: international business management environment, emerging economies, BRIC(S), the Next Eleven, New Development Bank.

JEL: M16, M21, N20, N30, O15, O30, O57, P30, P52.

* Corresponding author: rlittrell@hse.ru

This article has been prepared within the framework of a subsidy granted to the National Research University Higher School of Economics, Moscow, by the Government of the Russian Federation for the implementation of the Global Competitiveness Program.

a Postal Address: 3 Kantemirovskaya ul., National Research University Higher School of Economics at Saint Petersburg, St. Petersburg, 194100, Russia.

b Postal Address: College Rd, UNSW Business School, University of New South Wales, Kensington NSW 2052, Sydney, Australia.

(C) R.F. Littrell, P. Ramburuth, 2017

https://doi.org/10.21638/11701/spbu18.2017.407 
The BRIC countries (Brazil, Russia, India and China) were identified as the fastest growing emerging economies by the economist Jim O'Neill in 2001 [O'Neill, 2001]. He created the acronym BRIC (changed to BRICS in 2010 to include South Africa ${ }^{1}$ ) and placed emerging economies centre stage in the global economy, which seemed fitting at that time. O'Neill predicted increasing spending power, and increasing importance in international affairs. Given that BRIC(S) count for about $40 \%$ of the world's population, with over 3 billion people, they have massive potential markets and potential human capital to be tapped. Their growth has also presented other opportunities, including attracting international businesses to invest in them. Researchers, impressed by their elevation in the global economic environment (e.g. [Biggemann, Fam, 2011, p.1]), described them as "the best economic performers" in recent times. Others (e.g. [Wilson et al., 2011]), predicted that by 2050, the combined GDP of BRIC(S) would be larger than the G7 (the US, UK, Japan, Germany, France, Italy and Canada). All five BRIC(S) countries are members of the $\mathrm{G} 20 .^{2}$

1 While at Goldman Sachs, O'Neill has contended that South Africa's population of 50 million people, a fraction of Russia's 143 million and China's 1,34 billion people, is too small for BRIC status. At roughly $\$ 285$ billion in 2009 , South Africa's economy was less than one quarter that of Russia's, the smallest of the original BRIC country economies at about $\$ 1232$ billion. Nonetheless, South Africa remains a "member" of the bloc.

2 The G20 (or G-20 or Group of Twenty) is an international forum for the governments and central bank governors from Argentina, Australia, Brazil, Canada, China, France, Germany, India, Indonesia, Italy, Japan, Mexico, Russian Federation, Saudi Arabia, South Africa, South Korea, Turkey, United Kingdom, United States, and the European Union. Founded in 1999, the G20 aims to discuss policy pertaining to the promotion of international financial stability. It seeks to address issues that go beyond the responsibilities of any one organization. The G20 heads of government or heads of state have periodically conferred at summits since their initial
Although clustered as a bloc because of their impressive economic performance, researchers such as [Sinha, Dorschner, 2010, p. 88] noted that the four original BRIC countries were quite disparate, being separated geographically, culturally and politically, and had neither acted as a "natural trading bloc" nor conceived of themselves as such an entity. Some scholars, such as [Armijo, Burges, 2007; Tudoroiu, 2012] suggest a lack of conceptualization of BRIC(S) as a group. In fact, [Pant, 2013, p. 91] went as far as to refer to "The BRICS Fallacy", asserting that the group had begun to lose much of its shine. However, O'Neill had focused on what they all shared in 2001 , i.e. large populations, developing economies with upward trajectories, and governments that appeared willing to embrace global markets and some elements of globalization. To O'Neill, they all had the potential for rapid future economic growth, and these characteristics made them a natural cluster. O'Neill's categorization can be considered to have created the BRIC and BRIC(S) groups, as much as identifying the group.

The idea behind BRIC(S) was that the balance of global growth was shifting from the United States, Europe and Japan towards these emerging markets, with the prediction (e.g. [Lin, Rosenblatt, 2012]) that they would outperform many of the developed nations. They pointed out that between 2000 and 2012, China accounted for almost $25 \%$ of the global GDP rise, followed by India with a contribution of $5,8 \%$, Brazil with $3,1 \%$ and Russia with $1,8 \%$. But the predicted economic trajectory has not proved to be sustainable, as pointed out by [Kamm, 2016]. In 2016, China's economic growth decelerated sharply; India's growth rate levelled off; Brazil continues in political tur-

meeting in 2008, and the group also hosts separate meetings of finance ministers and foreign ministers due to the expansion of its agenda in recent years.

RMJ 15 (4): 515-536 (2017) 
moil and deep recession; and Russia's economy contracted by $4 \%$ in 2015 and continued to shrink in 2016 .

\section{The BRIC bloc and the international business management environment}

The study of management usually focusses upon understanding the management of people in organizations. The environmental aspect of the study of management focuses on the overarching societal cultural environment, and the specific national political, economic, legal, technological, and governmental influences. The majority of management studies are structured as empirical studies of employees, supervisors, manager, executives, and organizations, occasionally including national or country level analysis. The initial objective of this study was an analysis of the national data for the BRIC(S) bloc of countries, investigating the credibility of the forecasts of the positions of countries in the global economy in 2050. In structuring our study to focus on management issues in the BRIC(S) bloc, we draw some conclusions from our review of the management literature (e.g. [Daniels, Radebaugh, Sullivan, 2015, ch.12-13], and from received knowledge from our many years of experience in international business teaching and research. The first set of knowledge is that a national economy is the product of business activities within the nation, created, driven, and controlled by business executives, managers, and their employees. An economy described by economists is the collection of data concerning the results of the business activities, usually reported two years after they happen. The driving components of a national economy are (see World Economic Forum 2014 data, discussed and referenced below):

1) national economic freedom, which leads to enhanced economic development;

2) results of the innovation activities of the entrepreneurs in the nation;
3) results of the activities of the small and medium enterprises within the nation;

4) results of the activities of the larger multinational enterprises headquartered in the nation.

The successful functioning of these components of an economy are influenced for better or worse by the environment generated by the national government, as will be the case between now and 2050 for the companies in the BRIC bloc nations. Good managers can successfully cope with poor economies, but life is easier in nations that do not interfere with business operations, or actively support them.

\section{BRIC(S)' fluctuating national economic performance}

Initially, the BRIC countries were grouped together by analysts such as O'Neill as being at roughly the same stage of growth, but clearly their differences are more salient than their similarities. It was and is unlikely that their economies can grow in unison; firstly, because most economies rarely do so, and, secondly, because their economic activities are different [Li, 2013]. For example, Brazil and Russia are big energy producers, which is the proximate cause (not the only one) for why their economies are now in recession. India, as a big consumer of energy, has done well out of the recent collapse in commodity prices. The real story of BRIC(S) is China: the rapid pace of growth of the world's most populous country is a significant driver of the global economy in the 21st century. As a big and inefficient user of energy, it has also driven the demand side of the commodities cycle. [Pant, 2013, p.97] notes that, whilst this newly acquired economic status has propelled China into becoming the second largest economy in the world, it has created "structural disparity between China and the rest of the BRIC(S) members" with implications for the dominant role it could play within the group. 
But even this has changed. China is trying to shift to a new model of growth, based on domestic consumption rather than manufacture for export. Its annual growth rate is below 7 percent [Canuto, 2014]. There's no iron law why fast-growing economies must slow down, but China's will. Its population is ageing and a shift to providing services rather than making goods will constrain improvements in productivity. Its productive capacity contains a huge amount of wasteful investment, exemplified by the glut of Chinese steel that has pushed down global prices. Brazil and Russia rode a wave of buoyant commodities revenues for years. Now they're suffering from a lack of diversification of their exports. There is little sign that Brazil is going to break out of the "middle-income trap"3 [Canuto, 2014]. Historically and statistically, emerging economies that secure very rapid growth for about a decade do not seem to be able to sustain it, as is evident in BRIC(S) (see, e.g. [Freeman, 1989; Freeman, Soete, 1997]).

There is also the link between economic performance and human capital that cannot be ignored. Researchers and educators point to each of the BRIC(S) countries' poor performance on the United Nation's Human Capital Index [UNDP, 2014], with [Pant, 2013, p. 97] commenting on "the problems of good governance and rising socio-economic inequalities that continue to plague all five counties". The intersection between successful economic performance and human capital development is well researched and the implications for sustained economic growth widely recognised [Carnoy et al., 2013], although this intersection is not explored at the micro level in the context of this paper. Relative performance of the

\footnotetext{
3 The term "middle-income trap" (MIT) usually refers to observed events where countries that have experienced rapid growth and thus quickly reached middle-income status, then for various reasons failed to overcome that income range to further catch up to the developed countries.
}

BRIC(S) economies over time can be seen in fig. 1.

\section{BRIC(S) countries in comparative perspective}

\section{Economic freedom}

It should be noted that economic freedom of a country has a significant, positive effect on economic growth. The Heritage Foundation $^{4}$ states that economic freedom is the fundamental right of every human to control his or her own labor and property. In an economically free society, individuals are free to work, produce, consume, and invest in any way they please. In economically free societies, governments allow labor, capital, and goods to move freely, and refrain from coercion or constraint of liberty beyond the extent necessary to protect and maintain liberty itself. The Foundation finds that economic freedom brings greater prosperity. The Heritage Foundation Index of Economic Freedom documents the positive relationship between economic freedom and a variety of positive social and economic goals. The ideals of economic freedom are strongly associated with healthier societies, cleaner environments, greater per capita wealth, human development, democracy, and poverty elimination.

In table 1 , we see that the highest ranking of the BRIC(S) countries is South Africa at 72 out of 178 countries with scores. The remaining BRIC countries fall in the bottom two-thirds of the list. While this could have implications for opportunities for improvement of national economic performance, at the present time the BRIC countries are hampered in their economic development.

\section{Leveraging innovation} and entrepreneurship

INSEAD, Cornell University, and the World Intellectual Property Organization (WIPO),

\footnotetext{
${ }^{4}$ See http://www.heritage.org/index/about.
} 


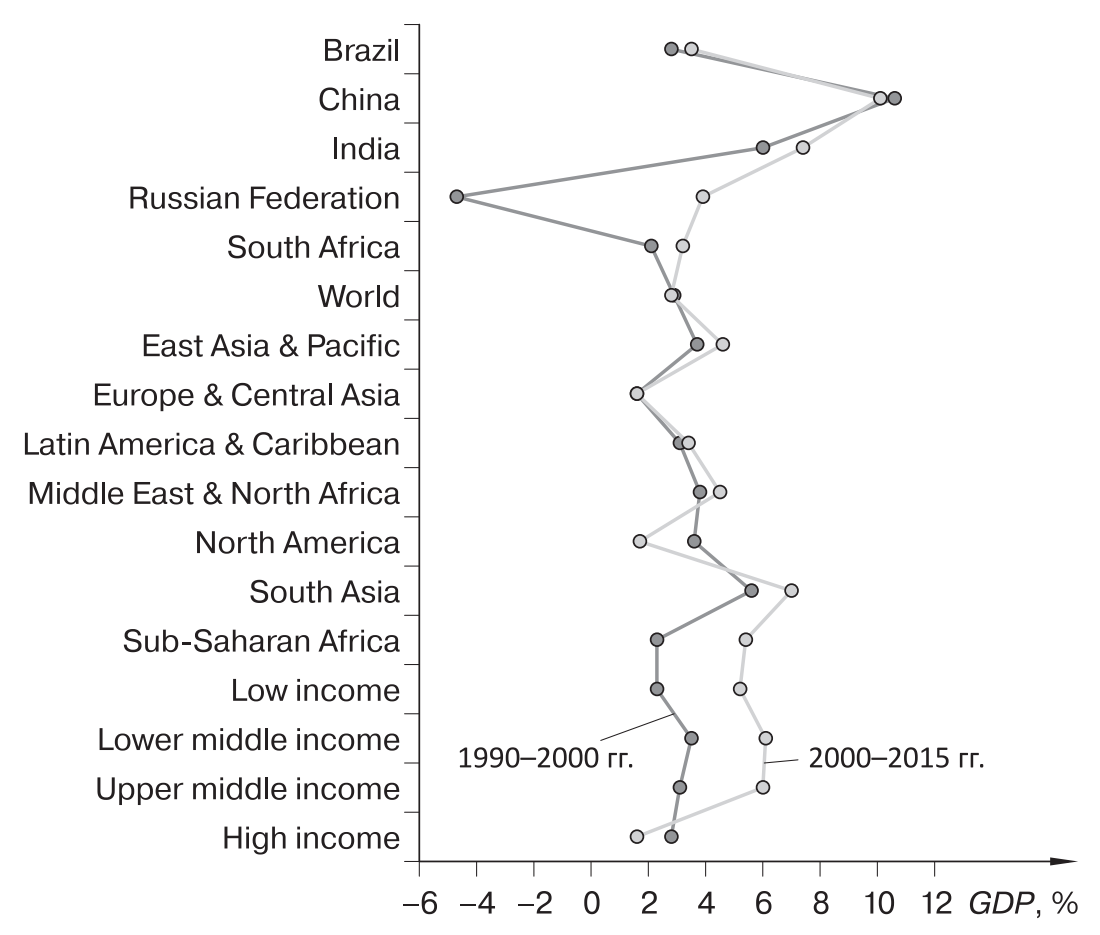

Fig. 1. Average annual GDP percent growth

S o u r c e: World Development Indicators, wdi.worldbank.org.

Table 1

Global list of Heritage Foundation Economic Freedom Index rankings, 2015

\begin{tabular}{l|r|l|c|l|c}
\hline \multicolumn{1}{c|}{ Country } & $\begin{array}{c}\text { World } \\
\text { Rank }\end{array}$ & \multicolumn{1}{c|}{ Country } & $\begin{array}{c}\text { World } \\
\text { Rank }\end{array}$ & Country & $\begin{array}{c}\text { World } \\
\text { Rank }\end{array}$ \\
\hline Hong Kong SAR (G. Cn) & $\mathbf{2}$ & $\mathbf{1}$ & $\mathbf{3}$ & $\mathbf{4}$ & $\mathbf{6}$ \\
\hline Singapore (G. Cn.) & 2 & Germany & 15 & South Korea & 29 \\
\hline New Zealand & 3 & Netherlands & 16 & Austria & 30 \\
\hline Australia & 4 & Bahrain & 17 & Malaysia & 31 \\
\hline Switzerland & 5 & Finland & 18 & Qatar & 32 \\
\hline Canada & 6 & Japan & 20 & Macau & 33 \\
\hline Chile & 7 & Luxembourg & 21 & St. Lucia & 34 \\
\hline Estonia & 8 & Georgia & 22 & Botswana & 35 \\
\hline Ireland & 9 & Sweden & 23 & Latvia & 36 \\
\hline Mauritius & 10 & Czech Rep. & 24 & Jordan & 37 \\
\hline Denmark & 11 & United Arab Emirates & 25 & Brunei Darussalam & 39 \\
\hline USA & 12 & Iceland & 26 & Belgium & 40 \\
\hline UK & 13 & Norway & 28 & Bahamas & 41 \\
\hline Taiwan & 14 & Colombia & Poland & 42 \\
\hline
\end{tabular}


Table 1 (continued)

\begin{tabular}{|c|c|c|c|c|c|}
\hline $\mathbf{1}$ & 2 & 3 & 4 & 5 & 6 \\
\hline Uruguay & 43 & Azerbaijan & 85 & Niger & 127 \\
\hline St. Vincent \& Grenadines & 44 & Dominican Rep. & 86 & India & 128 \\
\hline Cyprus & 45 & Guatemala & 87 & Suriname & 129 \\
\hline Barbados & 46 & Slovenia & 88 & Greece & 130 \\
\hline Peru & 47 & Morocco & 89 & Bangladesh & 131 \\
\hline Jamaica & 48 & Serbia & 90 & Burundi & 132 \\
\hline Spain & 49 & Swaziland & 91 & Yemen & 133 \\
\hline Slovak Rep. & 50 & Uganda & 92 & Maldives & 134 \\
\hline Costa Rica & 51 & Namibia & 93 & Mauritania & 135 \\
\hline Armenia & 52 & Lebanon & 94 & São Tomé and Príncipe & 136 \\
\hline Macedonia & 53 & Tonga & 95 & Papua New Guinea & 137 \\
\hline Hungary & 54 & Mongolia & 96 & Togo & 138 \\
\hline Bulgaria & 55 & Bosnia \& Herzegovina & 97 & China & 139 \\
\hline Oman & 56 & Fiji & 98 & Tajikistan & 140 \\
\hline Romania & 57 & Benin & 99 & Liberia & 141 \\
\hline$\overline{\text { Malta }}$ & 58 & Zambia & 100 & Comoros & 142 \\
\hline Mexico & 59 & Sri Lanka & 101 & Russia & 143 \\
\hline Cabo Verde & 60 & Burkina Faso & 102 & Guinea & 144 \\
\hline Dominica & 61 & Côte d'Ivoire & 103 & Guinea-Bissau & 145 \\
\hline El Salvador & 62 & Gabon & 104 & Cameroon & 146 \\
\hline Albania & 63 & Indonesia & 105 & Sierra Leone & 147 \\
\hline Portugal & 64 & Senegal & 106 & Vietnam & 148 \\
\hline Rwanda & 65 & Tunisia & 107 & Ethiopia & 149 \\
\hline Montenegro & 66 & Nicaragua & 108 & Lao P.D.R. & 150 \\
\hline Trinidad and Tobago & 67 & Tanzania & 109 & Haiti & 151 \\
\hline Panama & 68 & Cambodia & 110 & Nepal & 152 \\
\hline Kazakhstan & 69 & Moldova & 111 & Belarus & 153 \\
\hline Turkey & 70 & Djibouti & 112 & Micronesia & 154 \\
\hline Ghana & 71 & Gambia & 113 & Lesotho & 155 \\
\hline South Africa & 72 & Seychelles & 114 & Ecuador & 156 \\
\hline France & 73 & Bhutan & 115 & Algeria & 157 \\
\hline Kuwait & 74 & Honduras & 116 & Angola & 158 \\
\hline Thailand & 75 & Belize & 117 & Solomon Islands & 159 \\
\hline Philippines & 76 & Brazil & 118 & Uzbekistan & 160 \\
\hline Saudi Arabia & 77 & Mali & 119 & Burma & 161 \\
\hline Samoa & 78 & Nigeria & 120 & Ukraine & 162 \\
\hline Madagascar & 79 & Pakistan & 121 & Bolivia & 163 \\
\hline$\overline{\text { Italy }}$ & 80 & Kenya & 122 & Kiribati & 164 \\
\hline Croatia & 81 & Guyana & 123 & Chad & 165 \\
\hline Kyrgyz Rep. & 82 & Egypt & 124 & Central African Rep. & 166 \\
\hline Paraguay & 83 & Mozambique & 125 & Timor-Leste & 167 \\
\hline Vanuatu & 84 & Malawi & 126 & Congo, Dem. Rep. & 168 \\
\hline
\end{tabular}


Table 1 (continued)

\begin{tabular}{l|c|l|c|l|c}
\hline \multicolumn{1}{c|}{$\mathbf{1}$} & $\mathbf{2}$ & \multicolumn{1}{|c|}{$\mathbf{3}$} & $\mathbf{4}$ & \multicolumn{1}{c|}{$\mathbf{5}$} & $\mathbf{6}$ \\
\hline Argentina & $\mathbf{1 6 9}$ & Turkmenistan & $\mathbf{1 7 2}$ & Zimbabwe & $\mathbf{1 7 5}$ \\
\hline Congo Rep. & 170 & Equatorial Guinea & 173 & Venezuela & 176 \\
\hline Iran & 171 & Eritrea & 174 & Cuba & 177 \\
\hline & & & & North Korea & 178 \\
\hline
\end{tabular}

Note: G. Cn. - Greater China.

S ou r e: http://www.heritage.org/.

since 2007, collaborate to produce the Global Innovation Index (GII), and find that investments in R\&D and innovation are central to economic growth; helping developed countries reinvent themselves in times of economic decline and emerging countries answer their societies' growing needs. There are no BRIC(S) countries in the 2016 innovative top ten, see table 2 .

While science and innovation are more internationalized and collaborative than $\mathrm{ev}^{-}$ er before, countries sometimes tend to perceive each other as contenders rather than collaborators. Countries can overcome this by approaching innovation as a global positive effort instead of a zero-sum game. If the BRIC(S) bloc continues as an entity, we hope such a cooperative effort occurs. Review of the development literature (e.g. [Freeman, Soete, 1997]) also finds that sustained investment is critical. It may be tempting to scale back investment during times of lowgrowth or economic uncertainty, but it pays to keep it up as "stop-and-go" approaches quickly erase progress made in previous years.

Exceptional achievers in 2016. The INSEAD report of the latest Global Innovation Index (GII, also see [Rajput, Khanna, Oberoi, 2012]) finds only China of significant positive note in the BRIC(S) bloc in innovation support. China still only spends a small share of its research budget on basic R\&D in comparison to the innovation leaders, but its expenditures are getting closer to those of rich countries. It made a symbolic entry into the GII top 25 in 2016, the first middle income country to do so. The top 25 is typ-
Table 2

2016 top 10 in innovations

\begin{tabular}{r|l}
\hline 1 & Switzerland \\
\hline 2 & Sweden \\
\hline 3 & United Kingdom \\
\hline 4 & United States \\
\hline 5 & Finland \\
\hline 6 & Singapore \\
\hline 7 & Ireland \\
\hline 8 & Denmark \\
\hline 9 & Netherlands \\
\hline 10 & Germany \\
\hline
\end{tabular}

S o u r c e: [The World's Most Innovative..., 2016].

ically comprised of high income countries. China's progress has been remarkable in innovation quality, output and efficiency. Similar improvements have also helped other middle-income countries such as Bulgaria (38), Costa Rica (45) and Romania (48). Among the lower income countries, Moldova (46), Ukraine (56) and Vietnam (59) all outperform their peers in the same income group by at least 10 percent. Thus, China's progress can possibly be seen as a harbinger for future advancements, bridging the divide between rich and poor countries, an ongoing and defining feature of the GII.

\section{Small and medium enterprises} in the BRIC(S) bloc

The small business enterprise, in contrast to large multinational enterprises, is not a well-defined category, with overlaps in many countries with medium enterprises, and in many cases discussed as SMEs, Small and 
Medium Enterprises. The [OECD, 2000] defines SMEs as non-subsidiary, independent firms which employ fewer than a given number of employees, the most frequent upper limit suggested being 250 employees (for example, in the European Union). Microenterprises have 10, or in some cases five, workers. Many countries have large numbers of single-proprietor shops. In some countries financial assets are also used to define SMEs.

SMEs play a major role in economic growth in the OECD area, providing the source for most new jobs. Over $95 \%$ of OECD enterprises are SMEs, which account for $60-70 \%$ of employment in most countries. As larger firms downsize and outsource more functions, the weight of SMEs in the economy is increasing. In addition, productivity growth, and consequently economic growth, is strongly influenced by the competition inherent in the birth and death, entry and exit of smaller firms. This process involves high job turnover rates and churning in labor markets which is an important part of the competitive process and structural change. Less than one-half of small startups survive for more than five years, and only a fraction develop into the core group of high-performance firms which drive industrial innovation and performance. This underscores the need for governments to implement policies and framework conditions that have a support firm creation and expansion, with a view to optimizing the contributions that these firms can make to growth.

Small business in China. There are more than 11,7 million "small" businesses in China, defined as those with less than $100 \mathrm{em}$ ployees and assets under US $\$ 4,8$ million for industry and $\$ 1,6$ million for other sectors. China's National Bureau of Statistics estimates that they account for about 77 percent of all companies - and up to 94 percent, if we count one-person shops. Most importantly, however, these firms are re- sponsible for about 70 percent of all jobs. By contrast, there are about 28 million small businesses in the United States, accounting for 55 percent of all jobs (see [Overcoming the Fear...]).

Small business in India. Due to the recent events affecting small businesses in India, this discussion is a bit longer than for other countries.

On 8 November 2016, Indian Prime Minister Narendra Modi stunned the country by banning $86 \%$ of the money in circulation. India's tens of millions of small firms, which analysts say account for $40 \%$ of the economy and provide $80 \%$ of its jobs, were particularly hard hit because they usually do business only in cash [Iyengar, 2017]. Modi's ban on 500-rupee $(\$ 7,70)$ and 1000 -rupee $(\$ 15,40)$ notes - the two largest denominations at the time - was followed by another huge change in 2017 that also hurt small businesses. The Indian government revised the tax system in July to replace a complex web of state tariffs with a single national tax. Small firms are finding it difficult to adapt. India's economic growth fell to a three-year low of $5,7 \%$ as a result. Two million people lost their jobs in the first six months of 2017. The cash ban severely damaged output and incomes over 2017.

The recent actions by the Indian Government, detrimental to small businesses in that country, have led to many articles in the news media relating the effects in the eyes of analysts and small business owners, e.g., comments from CNN's [Iyengar, $2017]^{5}$ :

- India has 100 million small and mediumsized firms that play a vital role in the economy. They are also vulnerable to sudden policy change. They are predominantly cash based, employ less than ten employees on average and are outside the

5 The quotes in this section are from CNNMoney (New Delhi), first published November 8, 2017: 9:06 AM ET. 
tax net. They are informal because they cannot afford the costs of formality.

- Modi's predecessor Manmohan Singh, an economist and former finance minister, said on Tuesday that the cash ban and tax reform had "broken the back" of small businesses.

- The government says its policies will benefit India in the long run by bringing more people under the country's notoriously small tax net and promoting digital payments.

- Finance minister Arun Jaitley called the cash ban "a watershed moment" that Indians would later look back on "with a great sense of pride".

Gupta, a Delhi plastics manufacturer, is not convinced. "The note ban, taxation they must have had some strategy behind doing it, I'm not saying that they didn't", he said. "But they should have shown a little leniency to small business owners like us". The warehouse opposite Gupta's was devoid of activity except for two carpenters contracted to build an office for the owner. Workers like them, who depend on daily wages, are now struggling to make ends meet. The duo said they used to be busy all month, but now work less than 10 days on an average. "There's no point of a government that lets poor workers starve to death".

Small business in Russia. The majority of micro and small enterprises operate in the services sector, because it is here that the cost of starting a business is low, and returns can be considerable. According to the World Bank, there are more than 500 criteria for classifying small businesses. The main law that regulates the boundaries of small business in Russia is the number of employees and revenue: A micro enterprise is a business that earns up to 60 million roubles (about $\$ 2$ million), or employs up to 15 people, while enterprises with earnings of under 400 million roubles (\$130 million), or up to 100 employees, belong to the small business sector; everything above this threshold is medium-sized or big business.

Russia has adopted national programs to support small businesses, and being in this category may offer some advantages to an enterprise, such as a special tax regime that greatly facilitates tax reports and minimizes contacts with fiscal agencies. However, the small-enterprise status may introduce some new limitations, experts believe. For example, representatives of micro and small businesses find it harder to get a bank loan or find other sources of financing. Entrepreneurs also complain about heavy taxes, high administrative costs, rampant corruption and services foisted on customers against their will.

It is more difficult for small businesses to counteract these phenomena than it is for big businesses, which, in Russia, have close links with the state. "A government official looks at his job as a source of benefits and extra earnings", says Dina Krylova, President of the Business Perspective Fund, which protects entrepreneurs (see [Shpigel, 2013]). "The last thing they care about is preserving small businesses. And yet it means jobs and taxes", she says. In developed countries, entrepreneurs are valued much higher.

Nonetheless, 10 percent of Russia's population is engaged in small business. This is much less than in Europe, the U.S. or China. In Russia, the most successful small businesses are car repair shops and dealerships, and sellers of other consumer durables, which account for almost a third of the market, according to the Federal State Statistics Service for 2012. Next come real estate and construction operations, which account for another 30 percent of small enterprises. The processing industry (textiles, metalworking and electrical equipment producers, etc.) occupies nearly 15 percent; agriculture, hotels and restaurants, and transport and communications account for about 5 percent. "Russia is short on entrepreneurs 
in the innovation sphere and in high-tech business", Krylova says.

Small business in Brazil. Agencia Sebrae ${ }^{6}$ reports micro and small enterprises account for $98,5 \%$ of the total entrepreneurs in Brazil, account for $27 \%$ of the national GDP, and generate more than half of the jobs in the country [Agencia Sebrae, 2017]. A Government program of tax formalization, innovation, reducing bureaucracy, increasing access to credit and improving the legal environment are part of Sebrae's commitment to small businesses. Agenciasebrae.com.br reports that from 2007 through 2016, the number of small businesses in Brazil increased from 2,5 million to 11,6 million, or an average growth of almost one million small businesses per year. According to a Sebrae study, entrepreneurship is expected to continue to rise, and by 2022 , there will be 17,7 million individual micro entrepreneurs (MEI) and micro and small enterprises in the country. The effect of these events on Brazils global economic performance remains to be seen.

\section{The BRIC(S) and entrepreneurship}

Consistent with the growing number of entrepreneurs setting up start-ups and other business enterprises in countries across the globe, there is an increasing number of entrepreneurs engaging in Business in the BRIC(S) countries, seeking to leverage the stronger trends in economic growth in their home countries. Entrepreneurs may or may not be effective managers; however, entrepreneurs whose companies succeed and grow generate jobs that include managerial and supervisory jobs and employment for workers. They improve economies and people's lives by creating jobs, developing new solutions to problems, creating technology that improves efficiency and exchanging ideas

${ }^{6}$ See, http://www.agenciasebrae.com.br/sites/ asn.

RMJ 15 (4): 515-536 (2017) globally. Many of the conditions that help entrepreneurs also help the economy, providing even broader gains from supporting entrepreneurship.

Entrepreneurs improve economies and people's lives by creating jobs, developing new solutions to problems, creating technology that improves efficiency, and exchanging ideas globally. Many of the conditions that help entrepreneurs also help the economy, providing even broader gains from supporting entrepreneurship. The link between entrepreneurship and economic development and advancement is evident in the Global Entrepreneurship Index discussed below.

\section{Global Entrepreneurship Index}

The Global Entrepreneurship and Development Institute (The GEDI Institute) is a nonprofit organization that advances research on links between entrepreneurship, economic development and prosperity. The institute was founded by world-leading entrepreneurship scholars from the London School of Economics, George Mason University, University of Pécs, and the Imperial College London. The main contribution of the GEDI Institute is the GEI index, measuring the quality and dynamics of entrepreneurship environments at a national, regional and local level. The GEI index methodology has been validated in rigorous academic peer reviews. The methodology has also been endorsed by the European Commission and has been used to inform the allocation of EU Structural and Cohesion Funds. The theoretical approach of The GEDI Institute has also influenced entrepreneurship policy thinking in transnational organizations such as United Nations Conference on Trade and Development. The GEDI Institute creates an index of entrepreneurial activities for a set of countries each year (see: https:// thegedi.org).

Support and development of entrepreneurial activity is a useful variable in attempts to validate the various forecasts for 
the BRIC(S) bloc in 2050. Table 3 depicts the most recent (2017) global comparison index.

\section{The multinational corporation in the BRIC(S) bloc}

The Multinational Corporation or enterprise (MNE) is the primary player in international business. MNEs are now present in virtually every industry. When we discuss a nation's economy in an international context, we refer to a large part to the business activities of the MNEs headquartered in that country (usually reported by economists and considered two years after they happened), and in some cases to the incoming Foreign Direct Investment into the country by MNEs headquartered in foreign locations. A reasonable assumption is that

Table 3

Quality of entrepreneurship environment for a set of countries for 2017

\begin{tabular}{|c|c|c|c|c|c|c|c|c|}
\hline \begin{tabular}{c|} 
Global \\
Rank
\end{tabular} & Country & Score & \begin{tabular}{c|} 
Global \\
Rank
\end{tabular} & Country & Score & $\begin{array}{c}\text { Global } \\
\text { Rank }\end{array}$ & Country & Score \\
\hline 1 & 2 & 3 & 4 & 5 & 6 & 7 & 8 & 9 \\
\hline 1 & United States & 83,6 & 28 & Japan & 51,5 & 55 & Barbados & 33,6 \\
\hline 2 & Switzerland & 80,4 & 29 & Lithuania & 51,1 & 56 & Costa Rica & 33,3 \\
\hline 3 & Canada & 79,2 & 30 & Poland & 50,4 & 57 & South Africa & 32,9 \\
\hline 4 & United Kingdom & 77,8 & 31 & Portugal & 48,8 & 58 & Malaysia & 32,7 \\
\hline 5 & Australia & 75,5 & 32 & Cyprus & 48 & 59 & Lebanon & 31,5 \\
\hline 6 & Denmark & 74,3 & 33 & Oman & 46,9 & 60 & Montenegro & 31,2 \\
\hline 7 & Iceland & 74,2 & 34 & Spain & 45,3 & 61 & Namibia & 31,1 \\
\hline 8 & Ireland & 73,7 & 35 & Bahrain & 45,1 & 62 & Azerbaijan & 30,5 \\
\hline 9 & Sweden & 73,1 & 36 & Slovakia & 44,9 & 63 & Belize & 30 \\
\hline 10 & France & 68,5 & 37 & Turkey & 44,5 & 64 & Kazakhstan & 29,7 \\
\hline 11 & Netherlands & 68,1 & 38 & Czech Republic & 43,4 & 65 & Morocco & 29,2 \\
\hline 12 & Finland & 67,9 & 39 & Kuwait & 42,8 & 66 & Macedonia & 29,1 \\
\hline 13 & Hong Kong & 67,3 & 40 & Tunisia & 42,4 & 67 & Peru & 28,4 \\
\hline 14 & Austria & 66 & 41 & Puerto Rico & 42,1 & 68 & India & 28,4 \\
\hline 15 & Germany & 65,9 & 42 & Italy & 41,4 & 69 & Bulgaria & 27,8 \\
\hline 16 & Israel & 65,4 & 43 & China & 41,1 & 70 & Panama & 27,7 \\
\hline 17 & Belgium & 63,7 & 44 & Latvia & 40,5 & 71 & Thailand & 27,4 \\
\hline 18 & Taiwan & 59,5 & 45 & Saudi Arabia & 40,2 & 72 & Iran & 26,8 \\
\hline 19 & Chile & 58,5 & 46 & Romania & 38,2 & 73 & Ukraine & 26,8 \\
\hline 20 & Luxembourg & 58,2 & 47 & Colombia & 38,2 & 74 & Serbia & 26,4 \\
\hline 21 & Norway & 56,6 & 48 & Greece & 37,1 & 75 & Mexico & 26,4 \\
\hline 22 & Qatar & 55 & 49 & Jordan & 36,5 & 76 & Egypt & 25,9 \\
\hline 23 & Estonia & 54,8 & 50 & Hungary & 36,4 & 77 & Georgia & 25,8 \\
\hline 24 & South Korea & 54,2 & 51 & Uruguay & 35,0 & 78 & Russia & 25,2 \\
\hline 25 & Slovenia & 53,8 & 52 & Botswana & 34,9 & 79 & Gabon & 25 \\
\hline 26 & UAE & 53,5 & 53 & Brunei & 34,3 & 80 & Algeria & 24,7 \\
\hline 27 & Singapore & 52,7 & 54 & Croatia & 34,0 & 81 & Trinidad \& Tobago & 24,4 \\
\hline
\end{tabular}


Table 3 (continued)

\begin{tabular}{|c|c|c|c|c|c|c|c|c|}
\hline $\mathbf{1}$ & 2 & 3 & 4 & 5 & 6 & 7 & 8 & 9 \\
\hline 82 & $\begin{array}{l}\text { Dominican } \\
\text { Republic }\end{array}$ & 24,3 & 101 & Nigeria & 19,7 & 120 & Pakistan & 15,6 \\
\hline 83 & Albania & 24,2 & 102 & Zambia & 19,6 & 121 & Cameroon & 15,4 \\
\hline 84 & Philippines & 24,1 & 103 & Senegal & 19,2 & 122 & Nicaragua & 14,7 \\
\hline 85 & Argentina & 24 & 104 & Libya & 18,9 & 123 & Angola & 14,4 \\
\hline 86 & Swaziland & 23,8 & 105 & Côte d'Ivoire & 18,9 & 124 & Mozambique & 14 \\
\hline 87 & Vietnam & 23,2 & 106 & Paraguay & 18,7 & 125 & Madagascar & 14 \\
\hline 88 & Armenia & 22,8 & 107 & Honduras & 18,7 & 126 & Venezuela & 13,8 \\
\hline 89 & Jamaica & 22,2 & 108 & Guatemala & 18,5 & 127 & Myanmar & 13,6 \\
\hline 90 & Sri Lanka & 21,9 & 109 & Kenya & 18,4 & 128 & Benin & 13,3 \\
\hline 91 & Rwanda & 21,5 & 110 & Ethiopia & 18,3 & 129 & Burkina Faso & 13,2 \\
\hline 92 & Moldova & 21,2 & 111 & Suriname & 18,1 & 130 & Guinea & 12,9 \\
\hline 93 & Ghana & 21,0 & 112 & Lao PDR & 17,8 & 131 & Uganda & 12,9 \\
\hline 94 & Indonesia & 20,7 & 113 & Cambodia & 17,6 & 132 & Sierra Leone & 12,3 \\
\hline 95 & $\begin{array}{l}\text { Bosnia- } \\
\text { Herzegovina }\end{array}$ & 20,7 & 114 & El Salvador & 16,7 & 133 & Malawi & 12,2 \\
\hline 96 & Ecuador & 20,5 & 115 & Tanzania & 16,4 & 134 & Bangladesh & 11,8 \\
\hline 97 & Bolivia & 20,4 & 116 & Guyana & 16,4 & 135 & Burundi & 11,8 \\
\hline 98 & Brazil & 20,3 & 117 & Gambia, The & 16,1 & 136 & Mauritania & 10,9 \\
\hline 99 & Tajikistan & 20,0 & 118 & Mali & 15,9 & 137 & Chad & 9 \\
\hline 100 & Kyrgyz Republic & 19,8 & 119 & Liberia & 15,7 & & & \\
\hline
\end{tabular}

S o u r ce: Global Entrepreneurship and Development Institute, https://thegedi.org/global-entrepreneurshipand-development-index/.

a successful multinational company has an effective global management team, that it is well-managed, so we investigate MNE numbers in the BRIC bloc countries (South Africa has none).

If we take total revenues generated as a measure of the success of a company, we can use the Forbes magazine Global 500 largest companies as an indicator of the relative success of the population of managers working in businesses in a country.

FORBES Magazine Global 500. Forbes magazine annually ranks companies based on total revenues. For the 2017 international 500 rankings USA companies occupied 131 places of the 500 (see table 4). Of the 369 non-USA companies, China led with 109 placements. The remainder of the BRIC(S) fared poorly, with the BRI in total having 18 companies on the list. Geographic and population size have some influence, with 14 companies each on the list.

\section{BRIC(S) bloc: Business development perspectives}

Opportunities for business managers to influence economic growth. In the reports and reviews of the significant environmental situations for businesses in the BRIC(S) bloc, in member countries other than China, we do not see strong indications that business managers will be able to drive their companies to their maximum potential in the BRIC(S) national environments. Exceptionally competent managers can often overcome adverse environments, however, in member countries other than China the negative environment will be very difficult to deal with. 
Table 4

Forbes magazine international 500 largest companies 2017, by country

\begin{tabular}{l|c|c|l|c|c}
\hline \multicolumn{1}{c|}{ Country } & $\begin{array}{c}\text { No. } \\
\text { of enterprises }\end{array}$ & \multicolumn{1}{c|}{ Percent of total } & \multicolumn{1}{c|}{ Country } & $\begin{array}{c}\text { No. } \\
\text { of enterprises }\end{array}$ & $\begin{array}{c}\text { Percent } \\
\text { of total }\end{array}$ \\
\hline Total USA & 131 & $26,2 \%$ of the 500 & Russia & 4 & 1,1 \\
\hline Total Non-USA & 369 & $100,0 \%$ & Singapore & 3 & 0,8 \\
\hline China & 109 & $29,5 \%$ of the non-USA & Sweden & 3 & 0,8 \\
\hline Japan & 51 & 13,8 & Mexico & 2 & 0,5 \\
\hline Germany & 30 & 8,1 & Belgium & 1 & 0,3 \\
\hline France & 29 & 7,9 & UK \& Netherlands & 1 & 0,3 \\
\hline UK & 23 & 6,2 & Denmark & 1 & 0,3 \\
\hline South Korea & 15 & 4,1 & Finland & 1 & 0,3 \\
\hline Netherlands & 14 & 3,8 & Indonesia & 1 & 0,3 \\
\hline Switzerland & 14 & 3,8 & Israel & 1 & 0,3 \\
\hline Canada & 11 & 3,0 & Luxembourg & 1 & 0,3 \\
\hline Spain & 9 & 2,4 & Malaysia & 1 & 0,3 \\
\hline Australia & 7 & 1,9 & Norway & 1 & 0,3 \\
\hline Brazil & 7 & 1,9 & Saudi Arabia & 1 & 0,3 \\
\hline India & 7 & 1,9 & Thailand & 1 & 0,3 \\
\hline Italy & 7 & 1,9 & Turkey & 1 & 0,3 \\
\hline Taiwan & 6 & 1,6 & UAE & 1 & 0,3 \\
\hline Ireland & 4 & 1,1 & & & \\
\hline
\end{tabular}

Note: companies are ranked by size of revenues.

S o u r c e: http://fortune.com.

Improving the business environment in the $B R I C(S)$ bloc. Although divergent in their profiles and performance in many domains, with criticisms of lack of common purpose or significant performance as a bloc [Armijo, Burges, 2007; Tudoroiu, 2012; Pant, 2013], the BRIC(S) countries have sought to consolidate their relationships in strategic approaches with some impact. Commencing with regular annual meetings (since 2006) and more targeted agendas, they worked towards creating greater group cohesion and a collaborative presence in the global environment [Roberts, 2011]. Regular meetings between senior government officials, the inclusion of South Africa (in 2010) and the organization of the first BRIC summit in Russia in 2009, followed by annual summits in Brazil (2010), China (2011), India (2012), South Africa (2013), Brazil (2014), Russia (2015), and India
(2016) have all enabled a stronger collective voice on economic platforms [Tudoroiu, 2012; Li, 2013]. The impact of this collective voice on political platforms has been far greater than anyone had expected, including O'Neill.

Managers need money: The New Development Bank. Managers need money to succeed. In the BRIC(S) bloc, an indicator on the strengthening of the partnerships within the bloc is the establishment of the New Development Bank (NDB) in July 2015, also referred to as the BRICS Bank. The NDB commenced with initial capital of $\$ 50$ billion to provide resources for infrastructure building and sustainable development projects initially in the BRIC countries and then in other emerging economies [Pant, 2013], to be followed by $\$ 100$ billion for a Contingent Reserve Arrangement (CRA) to support the stabilization of 
currencies [Wihtol, 2014]. [Stuenkel, 2015; Wihtol, 2014] and others interpret this development by the BRIC(S) countries as presenting an alternative to the World Bank and International Monetary Fund (IMF). The NDB has been conceived as a counterbalance to the loan and grant conditions imposed by the US-led financial institutions by providing funding for infrastructure and development projects without conditional constraints, like those imposed by financial institutions such as the World Bank and IMF. The NDB is open to all UN country members, but structured to be controlled by the BRIC(S) countries, and the future of the BRIC(S) countries could be tied to the NDB. [Morozkina, 2015] concludes that the BRIC(S) countries have created a possible way to change the current system of development finance and therefore increase the role of the BRIC(S) countries in the global financial architecture. Time and the achievement of the goals set will tell whether the NDB was just "a much hyped up proposal" [Pant, 2013 p. 91] or an effective and powerful avenue for investment and development in BRIC(S) and other developing countries.

\section{Beyond BRIC(S) - Potential blocks for defining potentially collaborative business bloc environments}

The rise of $\mathrm{BRIC}(\mathrm{S})$ commenced a trend that identified and clustered emerging economies on their economic performance and potential for rapid economic growth. According to [Pant, 2013, p. 92], "the term BRICS soon became a brand", a brand that the member countries used to leverage their new-found prominence and influence in global economics as well as politics. But when the brand lost its sheen [Pant, 2013], and economic performance wavered, others stepped in. In 2005, Jim O'Neill and colleagues at Goldman Sachs [O'Neill et al., 2005] identified the Next Eleven (N-11) countries that they con- sidered had the highest potential to become the next cluster of the world's most important economies, and would rival the G7. This is despite the N-11 not having the same scale and impact of BRIC(S). These countries include: Bangladesh, Egypt, Indonesia, Iran, Mexico, Nigeria, Pakistan, the Philippines, Turkey, South Korea and Vietnam.

\section{The Next 11}

The Next 11 purportedly capture the "emergence of new poles of growth in different parts of the world coming mainly from the developing nations and newly industrialized economies..." [Labes, 2015]. The initial basis of the country grouping lies in indicators such as GDP growth, per capita income and population growth. [Lawson, Heacock, Stupnytska, 2007] identify other measures including energy, infrastructure, urbanisation, technology and human capital to assess both performance and potential for growth. Notably, they argued that "human capital is a critical to the long-term growth story" [Lawson, Heacock, Stupnytska, 2007, p.161]. In assessing the potential of individual countries within the G11 cluster, [Labes, 2015, p.247] notes that the two most likely economies to make a significant global impact are Mexico and South Korea, with the latter already being listed as "a high income per capita economy". The others, it seems, may find it challenging to keep the demanding pace set by fellow group members and by the high impact BRIC(S) cluster.

\section{MINT}

MINT is an acronym coined to include Mexico, Indonesia, Nigeria, and Turkey, which represents yet another group of countries with developing economies that are drawing attention. These four countries are listed by [O'Neill et al., 2005] as being part of the $\mathrm{N}-11$. All are newer, less established, and have relatively smaller populations than 
BRIC(S), but have been demonstrating exciting economic prospects for the future with their strong rates of economic growth. [Francesco, Ardita, 2015, p.38] note the "remarkable growth expected for the MINTs over the next 3 ears with Nigeria and Indonesia in the lead" with expected GDP growth rates between $5,5 \%$ and $6 \%$ by 2017 . They and researchers such [Kokotovic, $\mathrm{Ku}^{-}$ recic, 2016] point to added criteria that make the MINT countries attractive, which also signal further opportunities for development, although spread across four continents. These include their strategic positions as regional leaders; their large populations comprising youth which signals long term availability of a growing workforce; their strategic geographic positions, and plentiful supply of natural resources (natural gas and oil). These and other such converging factors have led to the conclusion that these countries, along with BRIC(S), have the highest potential for becoming some of the world's largest economies in the 21 st century.

\section{FIGS}

FIGS is an acronym coined to cluster the French, Italian, German, and Spanish economies. These four countries represent the strongest European markets with the greatest potential for success (despite recent hiccups in Spain). They also represent four languages that are considered essential, especially for companies from Englishspeaking countries when expanding into the European market(s). [Capita, n.d.] suggests that the acronym could be expanded to EFIGS, for example, if the English component is sufficiently significant. On a more pragmatic note, she points out that these languages use the Roman alphabet, it is therefore likely that most computer operating systems, applications, and printers, are already able to effectively deal with the languages - all good for going business and engaging in strategic partnerships across the group! Nevertheless, it is their strong economic performance that has caught the attention of the economists.

\section{Other contenders for the acronym of the next decade}

[Northam, 2014] notes that the acronym BRIC, (devised by O'Neill in 2001), has transformed the way in which we now view developing countries and their emerging markets. O'Neill followed up with MINT and others have sought to similarly identify emerging economies on strong trajectories. She cites Oliver Williams, an analyst for WealthInsight, who suggests that anyone wanting their fame in economics has come up with a grouping (see in [Northam, 2014]). He and others such as [Francesco, Ardita, 2015] list a variety of cluster countries including:

- MIST: Mexico, India, South Korea, Turkey;

- The Fragile Five (F-5): Indonesia, South Africa, Brazil, Turkey, and India;

- PINE: Philippines, Indonesia, Nigeria and Ethiopia;

- CIVETS: Colombia, Indonesia, Vietnam, Egypt, Turkey and South Africa;

- EAGLEs: Emerging and Growth Leading Economies (includes Brazil, China, Egypt, India, Indonesia, South Korea, Mexico, Russia, Taiwan and Turkey);

- MIKT: Mexico, Indonesia, South Korea and Turkey.

There may be others yet to come! Williams suggest that he might devise his own grouping, focusing on markets in Africa, particularly East Africa, noting that: "You've got Kenya, you've got Ethiopia, Tanzania, Uganda", which would give him KETU. Rearranged, he could end up with a catchier acronym KUTE [Northam, 2014]!

\section{Investment strategy or advertising campaign: Churning global FDI}

There are many unanswered questions and some cynicism surrounding the creation of 
country clusters based on what an economy yields in terms of percent GDP growth. Simplistically, churning in economic and business investment refers to unnecessary engagement in financial transactions, not based upon due diligence, that may or may not yield profit or growth, directed toward increasing transaction and consulting fees. In the global economy, FDI flows to areas which have certain advantages or are perceived to have advantages; for example, it flows in greater volume to South Africa than to other less-developed African countries. Middle-income countries have benefited from this at the expense of lower-income countries [Akinkugbe, 2003]. We will see if Nigeria receives the same benefit from inclusion in MINT or PINE.

The acronyms have the effect of an advertising and public relations campaign. For example, O'Neill's definition of BRIC led to the governments of these countries viewing themselves as a coalition, and business investors taking heart from public opinion that these were good places to invest. [Northam, 2014] draws attention to comments by Andrew Feltus, portfolio manager at Pioneer Investments, who notes that many emerg- ing markets bear strong similarities that include good fiscal policies and dynamic demographics. But there are also differences in terms of just how economically developed the countries are. According to Feltus, lumping four or five countries together under an acronym and forgetting the rest is an oversimplification. Quoted by Northam, he notes: "I'm kind of cynical on the whole idea. I think it's much more a marketing exercise than necessarily a true investment strategy". He points to Turkey, the final letter in the acronym MINT. It is a fast-growing economy, but the government has been battling corruption allegations and widespread street protests. He claims that he would rework MINT, omit Turkey and go for MINI, meaning Mexico, India, Nigeria and Indonesia. But Feltus says he does not recommend that anyone build a strategy based on MINI or any other acronym.

If we compile the actual performance of the BRIC(S) economies for the 10 years prior to their creation as a bloc, and the subsequent 15 years, we see that the BRIC(S) countries are questionable selections as a bloc in 2000, and did not perform as a bloc in the 2000-2015 period, see table 5 .

Table 5

Global positioning of economies conceptualized as having exceptional near-term future growth potential from the literature

\begin{tabular}{|c|c|c|c|c|c|}
\hline \multirow{2}{*}{ Bloc membership } & \multirow{2}{*}{ Economy } & \multicolumn{2}{|c|}{$\begin{array}{c}\text { Avg GDP } \\
\text { growth, \% }\end{array}$} & \multirow{2}{*}{$\begin{array}{c}2015 \text { GDP, } \\
\text { US } \$ \text {, } \\
\text { thousands }\end{array}$} & \multirow{2}{*}{$\begin{array}{c}2015 \\
\text { population, } \\
\text { thousands }\end{array}$} \\
\hline & & $\begin{array}{c}1990- \\
2000\end{array}$ & $\begin{array}{l}2000- \\
2015\end{array}$ & & \\
\hline \multirow[t]{3}{*}{$\mathbf{1}$} & 2 & 3 & 4 & 5 & 6 \\
\hline & World & 2,9 & 2,8 & & \\
\hline & USA & 3,6 & 1,7 & 18036648 & 319075 \\
\hline \multirow[t]{2}{*}{ BRICS, EAGLE } & China & 10,6 & 10,1 & 11064665 & 1401586 \\
\hline & Japan & 1,3 & 0,7 & 4383076 & 127061 \\
\hline \multirow[t]{2}{*}{ FIGS } & Germany & 1,7 & 1,1 & 3363447 & 81100 \\
\hline & UK & 2,6 & 1,4 & 2861091 & 64511 \\
\hline FIGS & France & 2,0 & 1,1 & 2418836 & 63920 \\
\hline BRICS, M\&M, F-5, EAGLE & India & 6,0 & 7,4 & 2088841 & 1275921 \\
\hline
\end{tabular}

RMJ 15 (4): 515-536 (2017) 
Table 5 (continued)

\begin{tabular}{|c|c|c|c|c|c|}
\hline $\mathbf{1}$ & 2 & & & 4 & 5 \\
\hline FIGS & Italy & 1,6 & $-0,2$ & 1821497 & 60783 \\
\hline BRICS, F-5 & Brazil & 2,8 & 3,5 & 1803653 & 202769 \\
\hline & Canada & 3,0 & 1,9 & 1552808 & 35871 \\
\hline NEXT11, M\&M, EAGLE & South Korea & 6,2 & 3,9 & 1377873 & 49750 \\
\hline BRICS, EAGLE & Russia & 4,7 & 3,9 & 1365865 & 146300 \\
\hline & Australia & 3,6 & 3,0 & 1339141 & 23923 \\
\hline FIGS & Spain & 2,7 & 1,1 & 1192901 & 47199 \\
\hline NEXT11, MINT, EAGLE & Mexico & 3,3 & 2,3 & 1143793 & 125235 \\
\hline NEXT11, MINT, F-5, PINE, EAGLE & Indonesia & 3,9 & 5,5 & 861934 & 255708 \\
\hline & Netherlands & 3,3 & 1,1 & 750284 & 16844 \\
\hline NEXT11, MINT, M\&M, F-5, CIVETS, EAGLE & Turkey & 3,9 & 4,5 & 717880 & 76690 \\
\hline & Switzerland & 1,2 & 1,9 & 670790 & 8238 \\
\hline & Saudi Arabia & 2,1 & 5,7 & 646002 & 29897 \\
\hline & Argentina & 4,3 & 3,9 & 584711 & 42154 \\
\hline EAGLE & Taiwan & 5,9 & 3,4 & 523006 & 23381 \\
\hline & Sweden & 2,3 & 1,9 & 495694 & 9693 \\
\hline NEXT11, MINT, PINE & Nigeria & 1,9 & 7,9 & 486793 & 183523 \\
\hline & Poland & 4,6 & 3,9 & 477066 & 38221 \\
\hline & Belgium & 2,2 & 1,4 & 455086 & 11183 \\
\hline NEXT11 & Iran & 2,4 & 3,9 & 425326 & 79476 \\
\hline & Thailand & 4,1 & 4,0 & 395168 & 67400 \\
\hline & Norway & 3,9 & 1,5 & 386578 & 5142 \\
\hline & Austria & 2,5 & 1,4 & 376950 & 8557 \\
\hline & UAE & 4,8 & 4,1 & 370296 & 9577 \\
\hline NEXT11, CIVETS, EAGLE & Egypt & 4,4 & 4,4 & 330779 & 86700 \\
\hline BRICS, F-5, CIVETS & South Africa & 2,1 & 3,2 & 314572 & 54002 \\
\hline & Hong Kong & 3,6 & 4,1 & 309235 & 7313 \\
\hline & Denmark & 2,8 & 0,8 & 301308 & 5617 \\
\hline & Israel & 5,7 & 3,8 & 299416 & 8212 \\
\hline & Malaysia & 7,0 & 4,9 & 296283 & 30600 \\
\hline & Singapore & 7,2 & 5,9 & 292739 & 5618 \\
\hline NEXT11, PINE & Philippines & 3,3 & 5,1 & 292451 & 99434 \\
\hline CIVETS & Colombia & 2,8 & 4,5 & 292080 & 49529 \\
\hline & Ireland & 7,5 & 2,5 & 283703 & 4610 \\
\hline NEXT11 & Pakistan & 3,8 & 4,2 & 271050 & 186190 \\
\hline & Chile & 6,6 & 4,0 & 240796 & 17819 \\
\hline & Finland & 2,9 & 1,1 & 232351 & 5451 \\
\hline & Portugal & 2,8 & 0,0 & 199113 & 10394 \\
\hline NEXT11 & Bangladesh & 4,7 & 5,9 & 195079 & 158217 \\
\hline & Greece & 2,4 & - & 194851 & 10993 \\
\hline
\end{tabular}


Table 5 (continued)

\begin{tabular}{|c|c|c|c|c|c|}
\hline \multirow{2}{*}{$\overline{\mathrm{NEXT11}}$} & 2 & \multicolumn{2}{|c|}{3} & \multirow{2}{*}{$\begin{array}{c}4 \\
193599\end{array}$} & \multirow{2}{*}{$\begin{array}{c}5 \\
90630\end{array}$} \\
\hline & Vietnam & 7,9 & 6,4 & & \\
\hline & Peru & 4,5 & 5,9 & 189111 & 31424 \\
\hline & Myanmar & 7,0 & 10,6 & 62601 & 51419 \\
\hline \multirow[t]{2}{*}{ PINE } & Ethiopia & 3,8 & 9,7 & 61540 & 88347 \\
\hline & Luxembourg & 4,5 & 2,7 & 56800 & 550 \\
\hline \multirow[t]{2}{*}{ Data from non-bloc countries omitted } & $\ldots$ & & & & \\
\hline & Tuvalu & 3,2 & 1,5 & 33 & 11 \\
\hline
\end{tabular}

N o t e: MIKT \& MIST (M\&M) include same countries; population data extracted from UN database.

S o u r e: data extracted from World Bank databases for 206 countries with data available.

\section{Conclusion}

O'Neill's original BRIC predictions employed four scenarios based on different methods of applying GDP paths, O'Neill saw the relative weight of the BRICs rising from $8 \%$ of world GDP in 2001 to $14,2 \%$ by 2011 . With each scenario, the increasing weight is led by China. In his "Next 10 years" section he makes several other predictions.

- On a PPP basis, China will be larger than Germany in 10 years.

- Of the four nations, China will have strongest growth, with Russia and India outpacing the G7, and Brazil experiencing weak "G7-style" growth.

- Brazil will "close in on" Italy in terms of GDP in 10 years.

- The EU would have increased its membership to 25 by 2007, up from 12 in 2001 . Looking at each of these predictions separately, O'Neill was more right than wrong, and conservative in his approach. If we look at the 2015 GDP on a Purchasing Power Parity (PPP) basis, the BRIC(S) bloc has a relatively lower standard of living and cost of living compared to developed countries. The comparison of PPP levels in 2015 are in table 6 .

In an address $^{7}$ by Mr. Daniel Mminele, Deputy Governor of the South African Reserve Bank, at the Bundesbank Regional Office in North Rhine-Westphalia, Düssel-

\footnotetext{
7 See: http://www.bis.org/review/r160720c.htm.
}

dorf, Germany, 7 July 2016, Mr. Mminele reports BRIC(S) economies have grown rapidly with their share of global GDP rising from 11 percent in 1990 to almost 30 percent in 2014. BRIC(S) accounted for over 40 percent of the world population, hold over US\$4 trillion in reserves and account for over 17 percent of global trade.

- Brazil has surpassed EU countries other than Germany in nominal GDP.

- The EU had 27 members by 2007.

- China's growth has surpassed predictions, achieving $13 \%$ of the world GDP in 2010 . [Labes, 2015, p.251] notes that "The rise of emerging markets has been perhaps the defining feature of the global economy this century". It certainly has promoted BRIC(S) as a group with a strong presence in the global economy, an increasing strong voice in political forums and proponents of a multipolar world structure. This is despite peaks and troughs in their economic trajectory and performance. Perhaps their future success could be linked to the success of the BRIC(S) Bank (NDP) and the delivery of its vision and development agenda in the BRIC(S) countries and beyond. Perhaps, too, the next decade will reflect the success or otherwise of the more recently emerging clusters of developing economies, and their ability to sustain performance in often volatile and unpredictable economic, political, social and technological environments. Those, like O'Neill, who identify trends in high performing emerging economies, and base their prediction of po- 
Gross domestic product 2015, PPP

Table 6

\begin{tabular}{|c|c|c|}
\hline Rank & Economy & PPP, millions of international dollars \\
\hline 1 & China & 19815111 \\
\hline 2 & United States & 18036648 \\
\hline 3 & India & 8003408 \\
\hline 4 & Japan & 5175259 \\
\hline 5 & Germany & 3924035 \\
\hline 6 & Russia & 3687406 \\
\hline 7 & Brazil & 3216169 \\
\hline 8 & Indonesia & 2848028 \\
\hline 9 & France & 2729182 \\
\hline 10 & United Kingdom & 2722455 \\
\hline 11 & Italy & 2260233 \\
\hline 12 & Mexico & 2157817 \\
\hline 13 & South Korea & 1753733 \\
\hline 14 & Saudi Arabia & 1688633 \\
\hline 15 & Spain & 1612867 \\
\hline 16 & Canada & 1586725 \\
\hline 17 & Turkey & 1574018 \\
\hline 18 & Iran & 1358795 \\
\hline 19 & Thailand & 1110458 \\
\hline 20 & Australia & 1100771 \\
\hline 21 & Nigeria & 1093921 \\
\hline 22 & Poland & 1020401 \\
\hline 23 & Egypt & 998667 \\
\hline 24 & Pakistan & 946667 \\
\hline 25 & Argentina & 883018 \\
\hline 26 & Netherlands & 840000 \\
\hline 27 & Malaysia & 817431 \\
\hline 28 & Philippines & 743898 \\
\hline 29 & South Africa & 725909 \\
\hline
\end{tabular}

S o u r ce: compiled from sources at https://www.revolvy.com.

tential impact on the global economy on percentages of economic data, may take on the challenging task of incorporating human development aspects of development and its multiple dimensions, given their proven intersection. Emerging economies, their country clusters and partnerships may appear and disappear, but it seems that their presence and influence in the global economy (albeit to varying degrees) is here to stay.

\section{Acknowledgements}

The authors would like to acknowledge the contribution made by Jacira Werle Rodrigues from her MPhil Thesis entitled An Analysis of BRIC's Performance, Economic Growth, Social Development and Future Challenges, 2016, University of New South Wales, Sydney, Australia (see [Rodrigues, 2016]). 


\section{REFERENCES}

Agencia Sebrae. 2017. Simples Incentivou a Criação de Empresas. [Electronic resource]. http://www.agenciasebrae.com.br/sites (accessed: 16.12.2017).

Akinkugbe O. 2003. Flow and Foreign Direct Investment to Hitherto Neglected Developing Countries. WIDER Discussion Papers No. 2003/02. World Institute for Development Economics (UNU-WIDER): Tokyo.

Armijo L.E., Burges S.W. 2007. The BRIC countries as analytical category: Miracle or insight? Asian Perspectives 31 (4): 7-42.

Biggemann S., Fam K.-S. 2011. Business marketing in BRIC countries. Industrial Marketing Management 40 (1): 5-7.

Canuto O. 2014. How Can Brazil Escape the Middle-income Trap? World Economic Forum, Geneva, Switzerland. [Electronic resource]. https://www.weforum.org/agen$\mathrm{da} / 2014 / 02 /$ can-brazil-escape-middle-income-trap/ (accessed: 17.12.2017).

Capita Translation and Interpreting. n.d. What Are FIGS, BRICS and MINT? Manchester, UK. [Electronic resource]. https:// www.capitatranslationinterpreting.com/ figs-brics-mint/ (accessed: 27.06.2017).

Carnoy M., Loyalka P., Dobryakova M., Dossani R., Froumin I., Kuhns K., Tilak J.B. G., Wang R. 2013. University Expansion in a Changing Global Economy: Triumph of the BRICs? Stanford University Press: Stanford, CA.

Daniels J.D., Radebaugh L.H., Sullivan D.P. 2015. International Business: Environment and Operations Global Edition. 15th ed. Prentice Hall: N.Y.

Francesco S., Ardita T. 2015. Markets' globalization and emerging economies. The MINTs economic growth: Developments and prospects. International Journal of Business and Commerce 5 (2): 38-55.

Freeman C. 1989. Technology Policy and Economic Performance. Pinter Publishers: UK.

Freeman C., Soete L. 1997. The Economics of Industrial Innovation. Psychology Press/ Routledge-Taylor \& Francis: Florence, KY.
Iyengar R. 2017. India's Small Firms Reel from 'Terrible Year' after Cash Ban. CNN (November, 8). [Electronic resource]. http:// money.cnn.com/2017/11/08/news/economy/india-cash-ban-one-year-small-businesses/index.html (accessed: 15.12.2017).

Kamm O. 2016. Building a strong case for a future in Europe with crumbling Brics. The Times (April, 21). [Electronic resource]. http://www.thetimes.co.uk/article/building-a-strong-case-for-a-future-ineurope-with-crumbling-brics-2fp5gslrb (accessed: 2.02.2017).

Kokotovic F., Kurecic P. 2016. The MINT countries: A regression analysis of the selected economic features. International Journal of Management Science and Business Administration 2 (5): 21-31.

Labes S.-A. 2015. Beyond BRICS - An Emerging Markets Economic Analysis. Centre for European Studies, University of IASI: Romania; 245-258.

Lawson S., Heacock D., Stupnytska A. 2007. Beyond the BRICs: A Look at the Next 11. [Electronic resource]. http://www.goldmansachs.com/our-thinking/archive/archivepdfs/brics-book/brics-chap-13.pdf (accessed: 28.06.2017).

Li P. 2013. Introduction. In: Li P., Gorshkov M.K., Scalon C., Sharma K.L. (eds). Handbook on Social Stratification in the BRIC Countries: Change and Perspective. World Scientific: London; $\mathrm{xv}-\mathrm{xxv}$.

Lin J.Y., Rosenblatt D. 2012. Shifting Patterns of Economic Growth and Rethinking Development. World Bank: Washington, DC.

Morozkina A. 2015. The New Development Bank in global finance and economic architecture. International Organisations Research Journal 10 (2): 68-80.

Northam J. 2014. The Global Economy: A World of Acronyms. National Public Radio (May, 13), Washington, DC. [Electronic resource]. http://www.npr.org/sections/parallels/2014/05/13/311852601/the-globaleconomy-will-mint-countries-be-the-newbrics (accessed: 02.02.2017). 
O’Neill J. 2001. Building Better Global Economic BRICs. Global Economics Paper No.66. Goldman-Sachs Research Group: London.

O'Neill J., Wilson D., Purushothaman R., Stupnytska A. 2005. How Solid Are the BRICs? Global Economics Paper No.134, Goldman Sachs: N. Y. (accessed: 28.06.2017). OECD. 2000. Small and Medium-sized Enterprises: Local Strength, Global Reach. Organisation for Economic Co-operation and Development: Washington, DC [Electronic resource]. http://www.oecd.org/cfe/leed/ 1918307.pdf (accessed: 15.12.2017).

Overcoming the Fear of Failure: Boosting Small Business in China. [Electronic resource]. https://www.huffingtonpost.com/ deborah-lehr/overcoming-the-fear-of-failure_b_7628686.html (accessed: 15.12.2017).

Pant $\bar{H} . \bar{V} .2013$. The BRICS fallacy. The $W a-$ shington Quarterly 36 (3): 91-105.

Rajput N., Khanna A., Oberoi S. 2012. Global innovation index and its impact on GDP of BRICS nations-innovation linkages with economic growth: An empirical study. Global Journal of Enterprise Information Systems 4 (2): 35-44.

Roberts C. 2011. Building the new order BRIC by BRIC. European Financial Review (February-March): 4-8.

Rodrigues J. W. 2016. An Analysis of BRIC's Performance: Economic, Growth, Social Development and Future Challenges. Master of Philosophy Thesis, UNSW Sydney. [Electronic resource]. http://unsworks. unsw.edu.au/fapi/datastream/unsworks:
40158/SOURCE02?view=true (accessed: 27.12.2017).

Shpigel M. 2013. Money to be made for small businesses in Russia. Russia Beyond (July, 30). () Rossiyskaya Gazeta. [Electronic resource]. https://www.rbth.com/business/ 2013/07/30/money_to_be_made_for_small_ businesses_in_russia_28497.html (accessed: 15.12.2017).

Sinha A., Dorschner J.P. 2010. India: Rising power or a mere revolution of rising expectations? Polity 42 (1): 74-99.

Stuenkel O. 2015. The BRICS and the Future of Global Order. Lexington Books: London.

The World's Most Innovative Countries, 2016. 2016. [Electronic resource]. https://knowledge.insead.edu/entrepreneurship/theworlds-most-innovative-countries-20164864 (accessed: 15.12.2017).

Tudoroiu T. 2012. Conceptualizing BRICS: OPEC as a mirror. Asian Journal of Political Science 20 (1): 23-45.

UNDP. 2014. Human Development Report 2014. Sustaining Human Progress: Reducing Vulnerabilities and Building Resilience. United Nations Development Program: N.Y.

Wihtol R. 2014. Whither Multilateral Development Finance? ADBI Working Paper No. 491 (July, 29). Available at SSRN: https://ssrn.com/abstract=2473489, http:// dx.doi.org/10.2139/ssrn.2473489 (accessed: 20.12.2017).

Wilson D., Trivedi K., Carlson S., Ursúa J. 2011. The BRICs 10 Years On: Halfway Through the Great Transformation. Global Economics Paper No.208. Goldman Sachs: N.Y.

Initial Submission: December 5, 2017

Final Version Accepted: December 22, 2017

\section{Среда международного бизнеса и ленеджлента в странах БРИК(С)}

\section{Р.Ф.Литрелл}

Национальный исследовательский университет "Высшая школа эконолики» - Санкт-

Петербург, Россия

E-mail: rlittrell@hse.ru 


\section{П. Рэлибурат \\ Школа бизнеса Университета Нового Южного Уэльса, Австралия \\ E-mail: p.ramburuth@unsw.edu.au}

В 2001 г. страны БРИК (Бразилия, Россия, Индия и Китай) были признаны Джимом О’Нилом в качестве наиболее быстрорастущих стран с развивающейся экономикой. Он создал акроним БРИК (который превратился в БРИКС в 2010 г. с включением Южной Африки) и предложил профиль стран, относимых к такой группе. Некоторые исследователи отмечали рост стран БРИКС как феноменальный, другие были более осторожными в своих оценках. Например, в [Sinha, Dorschner, 2010] отмечался весьма разрозненный характер стран БРИК, разделенных географически, культурно и политически. Другие исследователи (см., напр.: [Armijo, Burges, 2007; Tudoroiu, 2012]) отмечали отсутствие концептуализации БРИК(С) в качестве группы, которая имеет множество сходных характеристик. В данной статье рассматривается международная среда управления бизнесом в блоке стран БРИК(С), в которой обнаруживаются неопределенности относительно устойчивости их траектории роста. Исторически и статистически быстро растущие развивающиеся экономики кажутся неспособными выдержать его на десятилетних временнь́х интервалах, что проявляется в определенном снижении экономических показателей БРИК(С). В данной статье представлены статистические данные о характеристиках БРИК(C) по отдельным странам и блоку в целом, а также обсуждаются альтернативные группировки стран с развивающейся экономикой (например, FIG, MINT, MIST и т.д.) и прогнозы по ним. Кратко обсуждается роль Нового банка развития (создан в 2015 г.), призванного предоставлять финансирование для развития странам БРИКС и другим странам с развивающейся экономикой, а также его позиционирование в отношении других существующих финансовых институтов. Завершается статья предложениями по более взвешенной оценке стран с формирующимися рынками и их роли в мировой экономике.

Ключевые слова: среда международного бизнеса и менеджмента, формирующиеся экономики, БРИК(С), «Группа одиннадцати», Новый банк развития БРИК(С).

JEL: M16, M21, N20, N30, O15, O30, O57, P30, P52.

https://doi.org/10.21638/11701/spbu18.2017.407

Статья поступила в редакцию 5 декабря 2017 г. Принята к публикаиии 22 декабря 2017 г. 